\title{
Economic Policy Uncertainty and Corporate Innovation: Evidence From China
}

\author{
Huayu Shen ${ }^{1}$ (D) Man Zhang ${ }^{1}$, Runxin Liu ${ }^{1}$, Fei Hou ${ }^{2}$ a \\ ${ }^{1}$ Accouting and finance, North China Electric Power University, China, ${ }^{2}$ Qingdao University, China \\ Keywords: corporate innovation, managerial ownership, internal control, state-owned firms, economic policy uncertainty \\ https://doi.org/10.46557/001c.17192
}

\section{Asian Economics Letters}

Vol. 1, Issue 1, 2020

This study investigates whether economic policy uncertainty affects corporate innovation. Using a sample of Chinese listed firms during the period of 2007-2017, this paper finds that economic policy uncertainty is positively associated with corporate innovation. Moreover, firm-specific characteristics (state ownership, internal control, and managerial ownership) have an influence on the above relationship. Our paper contributes to the economic effects of economic policy uncertainty.

\section{Introduction}

In this article, we seek to examine the impact of uncertainty about economic policy on corporate innovation activities, which has received limited attention. Our hypothesis is that the economic policy uncertainty (EPU) promotes corporate innovation in the Chinese capital markets. The proposed effect of EPU on corporate innovation is motivated by real options theory (Folta \& O’Brien, 2004).

Our hypothesis test is important for the following reasons. In recent years, the uncertainty about economic policy is higher than ever before (Al-Thaqeb \& Algharabali, 2019; Baker et al., 2016). There is increasing concerns about whether and how this uncertainty would influence firm-level decisions and behaviors (Shen et al., 2020). Moreover, China is undergoing a transition period, essentially from a planned economy to a market-based economy (J. Chen et al., 2017). During this period, there are economic policy challenges that contribute to higher uncertainty (Y. Wang et al., 2014). With higher uncertainty and expectations to maximise economic growth, one key issue is how to enhance China's innovation ability. In order to promote innovation for sustained economic growth, the Chinese government has promulgated a series of policies (L. H. Fang et al., 2017).

Using Chinese data from the year 2007 to 2017, we show that EPU is positively related to innovation, implying that when firms face high uncertainty due to economic policy, firms have greater motivation to engage in innovative activities. Moreover, the empirical results document that firms with heterogeneous characteristics have different reactions to the EPU. Specially, the positive influence of policy uncertainty on innovation is more pronounced in state-owned firms, firms who have high-quality internal controls and firms with low managerial ownership.

This paper contributes to the literature in several important ways. First, our article is one of the few studies to empirically test the effect of EPU on corporate innovation. Our work is inspired by Bloom et al.'s (2007) call for more research on the relationship between uncertainty and innova- tion activities. F. He et al. (2020) provide evidence of the relationship between policy uncertainty and innovation. Our paper is different because we adopt the index developed by Baker et al. (2016), which has been widely used and can effectively capture real EPU. Moreover, our paper develops the hypothesis based on the real options theory and our results provide further support to the theory. Second, it is suggested in prior studies that firms with heterogeneous characteristics have different innovative abilities (Cheng et al., 2018; L. H. Fang et al., 2017). Our paper further explores whether firm-specific characteristics (the nature of ownership, internal control quality and managerial ownership) play a moderating role in the association between EPU and innovation activities. We, therefore, contribute to the literature on innovation and performance from a firm characteristic point of view.

\section{Hypothesis Development}

According to the real options theory, firms have a choice between waiting to obtain the deferred option or immediate investment to gain the growth option when facing uncertainty (Folta \& O'Brien, 2004). Specifically, the option to defer argues that firms delay the investment under uncertainty to avoid the opportunity costs related to an irreversible investment and wait for a better investment opportunity (McDonald \& Siegel, 1986). Alternatively, the option to growth obtains its value from early investment under uncertainty that provides the benefits of gaining future growth opportunities and competitive advantage (Kulatilaka \& Perotti, 1998). Considering the opposite influence of these two options on investment under uncertainty, the effect of uncertainty on investment depends on which option brings greater value (Folta \& O’Brien, 2004).

Furthermore, patents, as an output of innovation, are unduplicated and thus they give firms an exclusive right to discourage imitation. As a result, firms can obtain profits through patent transfer, which can partially offset the irreversibility of innovation investment (Bloom \& Van Reenen, 2002). In this regard, patent application can be considered as a reversibility option (Atanassov et al., 2015). The level 
of investments' irreversibility impacts the value of the option to defer. If the investments are completely reversible then the deferment option has no value. That is, higher reversibility is associated with lower valuable deferment options (Folta \& O'Brien, 2004). Therefore, innovation with its reversibility weakens the value of the deferment option and eventually highlights the value of the growth option. In this case, uncertainty concerning economic policy leads to more innovation. Thus, we specify hypothesis 1 as follows:

H1: Ceteris paribus, EPU is positively associated with corporate innovation.

State-owned firms usually have better access to valuable resources and policy information due to their close relationship with government (V. Z. Chen et al., 2014). As a result, state-owned firms are better to capture the changes about external economic policy in a timely manner and are capable of fostering innovation activities when faced with increased uncertainty. In contrast, non-state-owned firms have a disadvantage in accessing resources and thus they may not have enough capability to tackle increased EPU. Moreover, non-state-owned firms are "self-reliant" and have greater motivation to pursue innovation activities to ensure their development (Freund, 2001). Therefore, nonstate-owned firms may have lower sensitivity to EPU. Following this argument, we state hypothesis 2 as follows:

H2: Ceteris paribus, the positive effect of EPU on corporate innovation is more pronounced in state-owned firms.

Previous studies have pointed out that high quality internal control helps to improve financial information quality (Altamuro \& Beatty, 2010), reduce the information asymmetry between investors and mangers (Dhaliwal et al., 2011), and eventually reduce financing costs (Costello \& Wittenberg-Moerman, 2011). Thus, when facing uncertainty, strong internal control enables firms' better access to financial capital and, thereby, helps firms better seize the opportunity to innovate. Thus, based on these arguments, this paper hypothesizes that:

H3: Ceteris paribus, the positive effect of EPU on innovation is more pronounced in firms with high-quality internal control.

The alignment of managerial ownership could reduce the agency problem and motivate managers to make more effort to sustain firms' long-term development, which would encourage corporate innovation (Zahra et al., 2000). Based on the above discussions, we can see that firms with managerial ownership have more innovation, and therefore the innovation activity in these firms is less affected by the EPU. In other words, firms who have managerial ownership are less sensitivity to the impact of uncertainty on innovation. Following this argument, we propose hypothesis 4 as follows:

H4: Ceteris paribus, the positive effect of EPU on innovation is more pronounced in firms with low managerial ownership.

\section{Research Method}

In Hypothesis 1, we argue that EPU is positively associated with corporate innovation after controlling for other determinants. In order to test the hypothesis, we refer to the relevant studies (Juhro et al., 2020; Shen et al., 2020) and employ a model that incorporates the EPU, corporate innovation (PAT), firm-specific characteristics, and other potential factors, as follows:

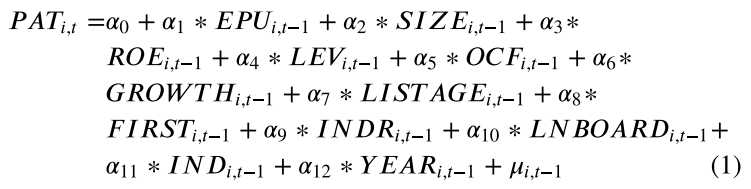

In Model (1), PAT is the dependent variable. We use the number of patent applications to measure innovation (Amore et al., 2013). There are three types of patents in China; these are invention patent, utility model patent, and design patent. Following studies, such as J. J. He \& Tian (2013) and V. W. Fang et al. (2014), we measure corporate innovation in three ways: the natural logarithm of $(1+$ patents) $\left(P A T_{1}\right)$, the natural logarithm of (1+invention patents), referred to as $P A T_{2}$, and the natural logarithm of (1+utility model patent + design patent), which we refer to as $P A T_{3}$. The independent variable is $E P U$. The independent variables including control variables are all one-period lagged. According to Hypothesis 1, we expect the coefficient on EPU $\left(\alpha_{1}\right)$ to be positive and statistically significant.

To empirically test Hypotheses $2-4$, we employ the following model:

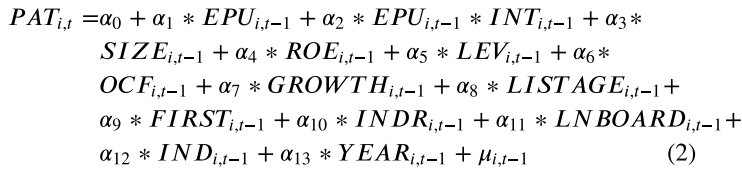

In Model (2), INT is the interactive variable, including STATE, IC and MASR, where STATE equals a value one if the ultimate controlling shareholder is a government agency or government controlled state-owned enterprises and 0 otherwise; IC stands for the index of internal control and risk from Dibo Enterprise Risk Management Technology Co., Ltd (DIB) database (F. Wang et al., 2018); and MASR is measured as the percentage of ownership held by top managers (Wu, 2008). 
Table 1: EPU and corporate innovation

\begin{tabular}{|c|c|c|c|}
\hline \multirow{2}{*}{ Variables } & (1) & $(2)$ & $(2)$ \\
\hline & $P A T_{1}$ & $P A T_{2}$ & $\mathrm{PAT}_{3}$ \\
\hline$E P U$ & $\begin{array}{c}0.191^{* * *} \\
(9.65)\end{array}$ & $\begin{array}{c}0.165^{* * *} \\
(8.56)\end{array}$ & $\begin{array}{c}0.176^{* * *} \\
(8.14)\end{array}$ \\
\hline Other control variables & YES & YES & YES \\
\hline YEAR and IND & YES & YES & YES \\
\hline Observations & 14959 & 14959 & 14959 \\
\hline $\operatorname{Adj} R^{2}$ & 0.352 & 0.308 & 0.373 \\
\hline
\end{tabular}

This table shows the regression results of the impact of $E P U$ on corporate innovation. PAT $_{1}$ is the first measure of corporate innovation, measured as the natural logarithm of (1+patents), $\mathrm{PAT}_{2}$ is the second measure of corporate innovation, measured as the natural logarithm of (1+invention patents), $\mathrm{PAT}_{3}$ is the third measure of corporate innovation, measured as the natural logarithm of (1+utility model patent + design patent) Significance levels at the $10 \%, 5 \%$, and $1 \%$ are denoted by ${ }^{*}, * *$, and ${ }^{* * * *}$, respectively. All reported $t$-statistics are based on standard errors adjusted for Huber-White (White, 1980). 
Table 2: The moderating effect of nature of ownership, internal control and managerial ownership

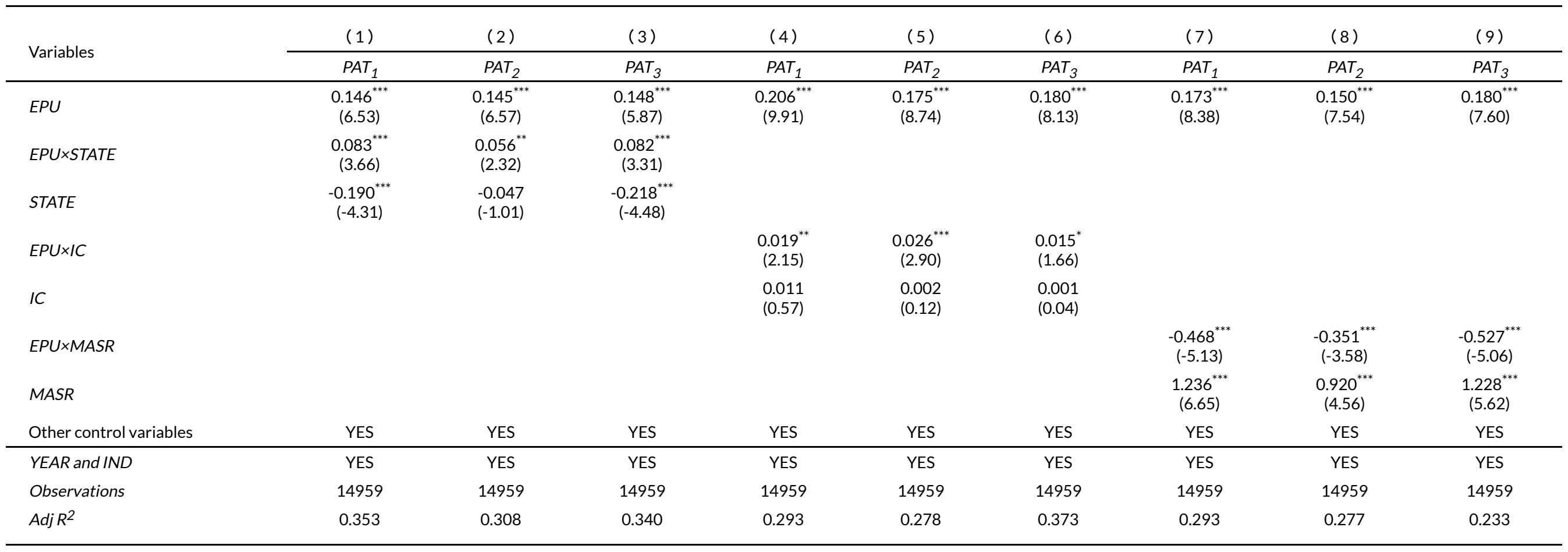

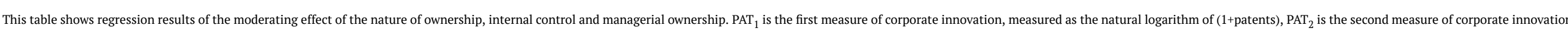

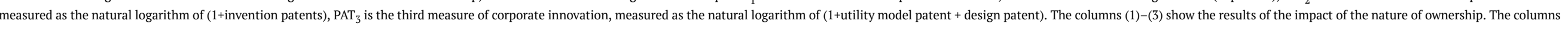

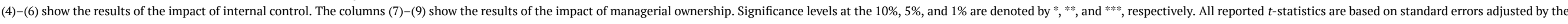
Huber-White (White, 1980) procedure. 


\section{Empirical Results}

\section{A. EPU and corporate innovation}

Table 1 tabulates the multivariate regression results relating to Hypothesis 1 that EPU positively influences corporate innovation. We find that the coefficients on $E P U$ are positive and highly significant $\left(0.191\right.$ with $t=9.65$ for $P A T_{1}$; 0.165 with $t=8.56$ for $P A T_{2}$; and 0.176 with $t=8.14$ for $\left.P A T_{3}\right)$. These results imply that firms promote corporate innovation in the face of uncertainty concerning economic policy and thus Hypothesis 1 is supported. In addition, the coefficient estimate on EPU means that innovation is about $16.5 \%$ to $19.1 \%$ higher for firms when facing high uncertainty.

\section{B. The moderating effect of the nature of ownership, internal control and managerial ownership}

The Hypotheses 2-4 examine whether the nature of ownership, internal control and managerial ownership moderate the relationship between EPU and PAT. We find that coefficients on $E P U \times S T A T E, E P U \times I C$ are significantly positive and coefficients on $E P U \times M A S R$ are significantly negative. These results indicate that the positive influence of $E P U$ on $P A T$ is more pronounced in state-owned firms, firms with strong internal control and firms with low managerial ownership, supporting Hypotheses 2-4.

\section{Robustness checks}

We conduct a number of robustness tests. Specially, we change the measurement of EPU and innovation and repeat the main analyses and find that the results remain unchanged. In addition, the fixed effects model and two-stage least squares (2SLS) approaches that we employed to address potential endogeneity issue produce consistent results (Shen et al., 2020). All additional results are available upon request.

\section{Conclusion}

This paper empirically tests the effect of EPU on corporate innovation. The empirical results suggest that when facing uncertainty, firms would promote innovation. Moreover, firm-specific characteristics (the nature of ownership, internal control quality, and managerial ownership) have an impact on the manner in which EPU impacts innovation. In addition, the positive relation between uncertainty and innovation is more pronounced in highly competitive industries and with firms characterized by low financial constraint.

\section{Acknowledgement}

We thank the editors and reviewers for useful comments and suggestions on earlier versions of this paper. This paper is part of a research project funded by Beijing Social Science Fund, China (19GLC074 and 2018BJ0608) and the Fundamental Research Funds for the Central Universities, China (2020MS044).

Submitted: August 07, 2020 AEDT, Accepted: September 09, 2020 AEDT 


\section{REFERENCES}

Altamuro, J., \& Beatty, A. (2010). How does internal control regulation affect financial reporting? Journal of Accounting and Economics, 49(1-2), 58-74. http s://doi.org/10.1016/i.jacceco.2009.07.002

Al-Thaqeb, S. A., \& Algharabali, B. G. (2019). Economic policy uncertainty: A literature review. The Journal of Economic Asymmetries, 20, e00133. http s://doi.org/10.1016/j.jeca.2019.e00133

Amore, M. D., Schneider, C., \& Žaldokas, A. (2013). Credit supply and corporate innovation. Journal of Financial Economics, 109(3), 835-855. https://doi.or $\mathrm{g} / 10.1016 /$ j.jfineco.2013.04.006

Atanassov, J., Julio, B., \& Leng, T. (2015). The bright side of political uncertainty: The case of R\&D. SSRN Electronic Journal. https://doi.org/10.2139/ssrn.26936 05

Baker, S. R., Bloom, N., \& Davis, S. J. (2016). Measuring Economic Policy Uncertainty. The Quarterly Journal of Economics, 131(4), 1593-1636. h ttps://doi.org/10.1093/aje/qjw024

Bloom, N., Bond, S., \& Van Reenen, J. (2007). Uncertainty and investment dynamics. The Review of Economic Studies, 74(2), 391-415. https://doi.org/1 0.1111/j.1467-937x.2007.00426.x

Bloom, N., \& Van Reenen, J. (2002). Patents, Real Options and Firm Performance. The Economic Journal, 112(478), C97-C116. https://doi.org/10.1111/ 1468-0297.00022

Chen, J., Jiang, F., \& Tong, G. (2017). Economic policy uncertainty in China and stock market expected returns. Accounting \& Finance, 57(5), 1265-1286. htt ps://doi.org/10.1111/acfi.12338

Chen, V. Z., Li, J., Shapiro, D. M., \& Zhang, X. (2014). Ownership structure and innovation: An emerging market perspective. Asia Pacific Journal of Management, 31(1), 1-24. https://doi.org/10.1007/s1 0490-013-9357-5

Cheng, Q., Goh, B. W., \& Kim, J. B. (2018). Internal control and operational efficiency. Contemporary Accounting Research, 35(2), 1102-1139.

Costello, A. M., \& Wittenberg-Moerman, R. (2011). The Impact of Financial Reporting Quality on Debt Contracting: Evidence from Internal Control Weakness Reports. Journal of Accounting Research, 49(1), 97-136. https://doi.org/10.1111/j.1475-679x.20 10.00388.x
Dhaliwal, D., Hogan, C., Trezevant, R., \& Wilkins, M. (2011). Internal Control Disclosures, Monitoring, and the Cost of Debt. The Accounting Review, 86(4), 1131-1156. https://doi.org/10.2308/accr-10043

Fang, L. H., Lerner, J., \& Wu, C. (2017). Intellectual property rights protection, ownership, and innovation: Evidence from China. The Review of Financial Studies, 30(7), 2446-2477. https://doi.org/1 0.1093/rfs/hhx023

Fang, V. W., Tian, X., \& Tice, S. (2014). Does stock liquidity enhance or impede firm innovation? The Journal of Finance, 69(5), 2085-2125. https://doi.org/ 10.1111/jofi.12187

Folta, T. B., \& O’Brien, J. P. (2004). Entry in the presence of dueling options. Strategic Management Journal, 25(2), 121-138. https://doi.org/10.1002/smj.3 $\underline{68}$

Freund, E. M. (2001). FIZZ, FROTH, FLAT: The Challenge of Converting China's SOEs into Shareholding Corporations. Review of Policy Research, 18(1), 96-111. https://doi.org/10.1111/j.154 1-1338.2001.tb00969.x

He, F., Ma, Y., \& Zhang, X. (2020). How does economic policy uncertainty affect corporate Innovation?-Evidence from China listed companies. International Review of Economics \& Finance, 67, 225-239. https://doi.org/10.1016/i.iref.2020.01.006

He, J. J., \& Tian, X. (2013). The dark side of analyst coverage: The case of innovation. Journal of Financial Economics, 109(3), 856-878. https://doi.org/10.1016/ j.jfineco.2013.04.001

Juhro, S. M., Narayan, P. K., Iyke, B. N., \& Trisnanto, B. (2020). Is there a role for Islamic finance and R\&D in endogenous growth models in the case of Indonesia? Pacific-Basin Finance Journal, 62, 101297. https://doi.org/10.1016/i.pacfin.2020.101297

Kulatilaka, N., \& Perotti, E. C. (1998). Strategic growth options. Management Science, 44(8), 1021-1031. https://doi.org/10.1287/mnsc.44.8.1021

McDonald, R., \& Siegel, D. (1986). The Value of Waiting to Invest. The Quarterly Journal of Economics, 101(4), 707-727. https://doi.org/10.2307/ $\underline{1884175}$ 
Shen, H., Fu, M., Pan, H., Yu, Z., \& Chen, Y. (2020). The Impact of the COVID-19 Pandemic on Firm Performance. Emerging Markets Finance and Trade, 56(10), 2213-2230. https://doi.org/10.1080/1540496 X.2020.1785863

Wang, F., Xu, L., Zhang, J., \& Shu, W. (2018). Political connections, internal control and firm value: Evidence from China's anti-corruption campaign. Journal of Business Research, 86, 53-67. https://doi.o rg/10.1016/j.jbusres.2018.01.045

Wang, Y., Chen, C. R., \& Huang, Y. S. (2014). Economic policy uncertainty and corporate investment: Evidence from China [J]. Pacific-Basin Finance Journal, 26, 227-243. https://doi.org/10.101 6/j.pacfin.2013.12.008
White, H. (1980). A Heteroskedasticity-Consistent Covariance Matrix Estimator and a Direct Test for Heteroskedasticity. Econometrica, 48(4), 817-838. htt ps://doi.org/10.2307/1912934

Wu, H.-L. (2008). When does internal governance make firms innovative? Journal of Business Research, 61(2), 141-153. https://doi.org/10.1016/j.jbusres.200 7.06.010

Zahra, S. A., Neubaum, D. O., \& Huse, M. (2000). Entrepreneurship in Medium-Size Companies: Exploring the Effects of Ownership and Governance Systems. Journal of Management, 26(5), 947-976. htt ps://doi.org/10.1177/014920630002600509 